\title{
Assessment of Paddy Soil Quality Index Based on Differences in the Productivity of Paddy in Wonogiri Regency
}

\author{
Supriyadi \\ Departement of Soil Science, Faculty of Agriculture, \\ Sebelas Maret University, 57101, Surakarta, Indonesia \\ E-mail: supriyadi.tanah.fpuns@gmail.com \\ Retno Rosariastuti \\ Departement of Soil Science, Faculty of Agriculture, \\ Sebelas Maret University, 57101, Surakarta, Indonesia \\ E-mail: retnobs@yahoo.co.id
}

\section{Pranoto}

Departement of Chemistry, Faculty of Science and Mathematic, Sebelas Maret University, 57101, Surakarta, Indonesia E-mail:pak_pran@yahoo.com

Fitria Okvitasari

Departement of Agrotechnology, Faculty of Agriculture, Sebelas Maret University, 57101, Surakarta, Indonesia E-mail: vitriaokvitasari@gmail.com

Received: August 8, 2016 doi:10.5296/jas.v5i2.9742
Accepted: June 20, 2017

Published: June 29, 2017

URL: https://doi.org/10.5296/jas.v5i2.9742 


\begin{abstract}
Rice or paddy is a staple food in some countries. The need for food is huge as the population growth increase, in Wonogiri regency majority of the land area is used as paddy field and land intensification is done to improve productivity. Land intensification raises the issues of having no definitive measure about the status of soil improvement after the cultivation practices of Paddy (Oryza sativa) has been done, in addition, the diversity of age utilization of paddy field by farmers resulting the differences in productivity that will affect the quality difference of the paddy field soil. The assessment is aimed to determine the soil quality function whether it's good or bad after doing such land cultivation practices for a certain period. The assessment of soil quality is using data analysis method from the influential indicators based on the nature of at least the Minimum Data Set (MDS) that is obtained based on calculations of Principal Component Analysis (PCA). Indicators that affect, such as, C-Organic,Bulk Density, K-Available, N-Total, and average soil quality were obtained at all points of the sample with a diverse range of values. With the known SQI values, in the future the efforts to maintain and improve the quality of the soil can be done by considering several important factors.
\end{abstract}

Keywords: paddy soil, soil quality, productivity of paddy.

\title{
1. Introduction
}

Paddy is one of the seasonal crops that also a source of staple food for most people in Indonesia. According to Bezbaruha et al. (2011) the majority of the population in Asia is so depending on the secure of rice with a range of about $90 \%$ of the world population. The level of rice consumption in Wonogiri regency is in the amount of 91.411 tons in 2014 (Department of Food Security Wonogiri 2014). Since 2010 until 2013 Wonogiri regency is a Paddy producer with a sizeable number (BPS 2013). Not only in Indonesia, but also in Ethiopia the population growth and natural resource exploitation is suppressing the amount of agricultural land (Gelaw 2015). Land intensification on a large scale with a high input on the land to improve productivity resulted in soil degradation and damage the paddy field. Poor management and too intensively land use make the soil degraded, and this matter is a major discussion as an environmental and economic issue (Eswaran et al 1996). According to Danapriatna et al. (2012) that the paddy field quality tends to be decreased marked by the decrease of soil organic substance and soil ability in providing nutrients for plants. Soil quality is a parameter determining how good or bad a ground is in providing plant nutrition, water and other elements, according to Karlen (2003) assessment of soil quality is done to raise the awareness of the importance of soil resources with some existing characteristics of the soil. It considers the complexity of a soil covering human intervention, the function of soil and surrounding ecosystem (Franzzluber 2006). The purpose of the research is to determine the value of the index-quality paddy field in Wonogiri and the parameters that influence the quality of the soil at the same time determine the relationship between soil quality and level of productivity of paddy. 


\section{Material and Methodes}

\subsection{Field Survey}

The method used in this research is descriptive explorative. Information is collected from the survey obtained in the field and supported by laboratory analysis. The point of soil samples is determined by purposive sampling as the sample points deliberately chosen with consideration of the extents (> 10ha) and the results of an overlay of slope maps, soil types maps, land use maps, rainfall maps and then forming up (SPL). Observation point, measurement and sampling were determined by stratified random sampling method.

\subsection{Laboratory Analysis and Data Analysis}

Variables of the observation include the chemical, physical and biological characteristics of the soil. Data analysis methods used in determining soil quality indicator determined by the minimum characteristics of the most influential in determining the quality of the soil (MDS). Minimum Data Set is obtained based on calculations of Principal Component Analysis (PCA) using Minitab software 14.0.

\section{Result and Discussion}

\subsection{Description of the Area}

Wonogiri Regency is located in $7^{\circ} 32^{\prime}-8^{\circ} 15^{\prime}$ south latitude and longitude $110^{\circ} 41^{\prime}-111^{\circ} 18^{\prime}$ East Longitude with an average rainfall ranging between 1557-2476 mm / year (Pemkab 2015). Wonogiri consists of several types of soil, so its beneficiaries are also different. The majority of the land in Wonogiri regency is being used to grow food crops and plantations. Extensive paddy field in Wonogiri regency in the amount of 32.347 ha (17.9\%) while the dry field is in the amount of 149.889 ha (82.1\%) (Department of Agriculture 2012). This research was conducted in several districts of Wonogiri, the Wonogiri District, Selogiri District, Ngadirojo District, Girimarto District, Nguntoronadi District, Eromoko District and Jatiroto District with a total of 11 sample points.

The soil samples taken are located at a height of land varies from the lowest at $134 \mathrm{mdpl}$ in the Garon village in the Selogiri District and the highest at 544 meters mdpl in the Tambak Merang village in Girimarto District. The paddy field in Wonogiri were divided into three classes, namely: (a) flat (0-8\%), (b) corrugated (8-15\%), (c) hilly (15-30\%). According to Notohadiprawiro the preparation of a land to be used as paddy field soil will cause the physical, chemical and morphological characteristics of the soil in the real form. The nature of the soil will turn into an artificial soil conditions that deviated from the desired state by another planting. The process of soil changing back and forth indirectly represents an activity of the manipulation of depth soil resources. The sampling point done in several different soil types in Wonogiri Regency, there are three types of soil that can be found include: Mollisol, Alfisol and Inceptisol.

Paddy fields still apply the intensive farming systems that cause a lot of losses, including the reduction of biodiversity, degradation of soil in physical, chemical and biological. As Purwanto (2014) the intensification of agriculture that done by the farmers can affect the 
number and placement of crop residues as a result of their use of agrochemicals and soil processing, so that the changes can determine by the reduction in soil biodiversity. In this research, physical, chemical and biological soil analysis is done to determine the condition of the indicator supposed to influence the value of soil quality. The chemical, physical and biological characteristics of soil, soil can not be from the test results in the field and laboratory that are influenced by several important factors, including factors of the soil itself, the factors on the ground, either from the environment, human and animal life above the ground. From each of these indicators there will be mutual interactions that lead to their positive correlation or relationship and also the negative relationship. In the analysis of soil chemical property found that soil organic substance was negatively correlated with the value of N-total soil but instead the correlation between organic substance and available-P value and K-provided show a positive relationship. The lower the $\mathrm{pH}$ of the soil, the higher the value of the CEC and the soil N-Total is. As a result of the charge depends on the $\mathrm{pH}$ of the decisive moment in the laboratory analysis. Soil that has high clay content, the value of the CEC will be even greater, as well as soil organic substance content. The high content of soil organic substance will also result in high CEC content, but it did not happen after the test showed high correlation of CEC value that is not affected by high soil organic matter.

\subsection{Soil Quality Index Values and its Relation to Paddy Productivity}

Soil quality is an assessment tool of a soil management practice quantitatively, besides the quality is also an overview of the environment based on the consideration of the physical, biological and chemical properties of the soil (Karlen and Mausbach 2001). According to Supriyadi et al. (2013), the key role of soil quality is a tool to realize the ideals of sustainable agricultural development. Proper soil management will help maintain the productivity of biology, water, air, and human health (Kalu 2015). The quality of the soil will be related to the issues concerning food security, environmental sustainability and also food quality and food safety. Healthy and nutritious food becomes important because a healthy lifestyle is already being adopted by the wider community. Healthy food must come from healthy agricultural system. Here is an overview map of soil quality in Wonogiri regency. 


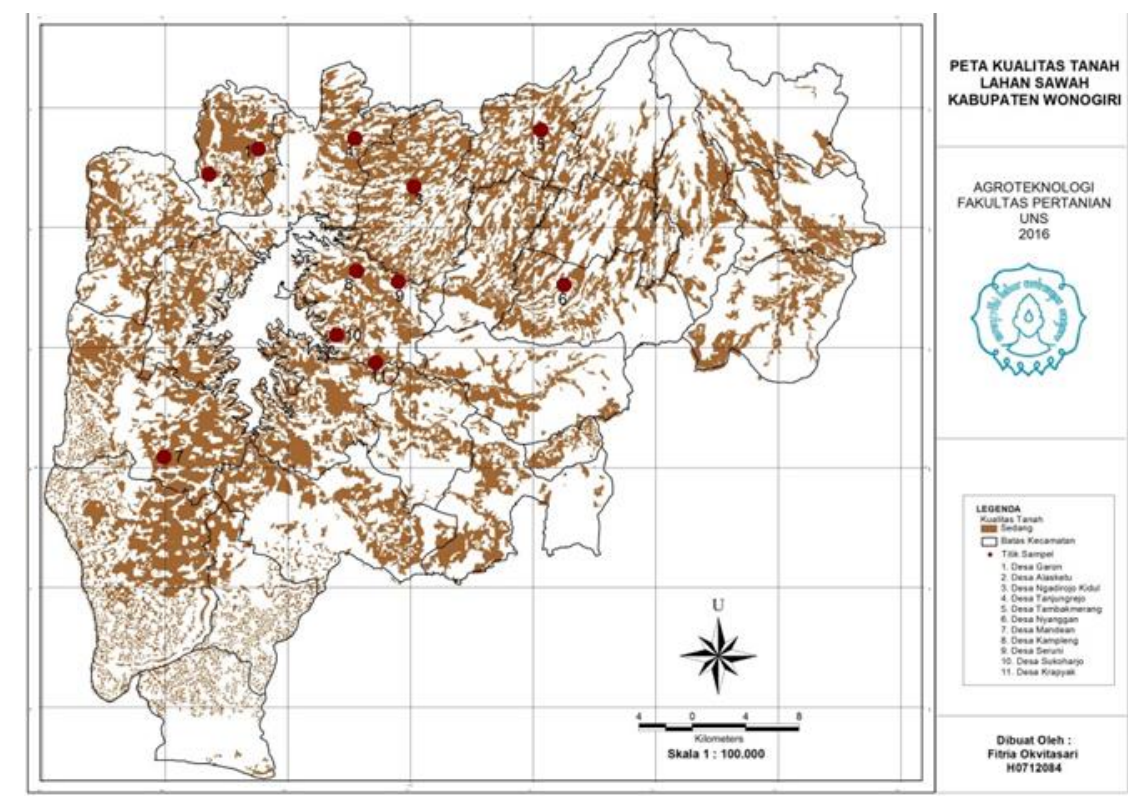

Figure 1. Maps of Soil Quality in Wonogiri Regency

Form all of the indicators that being observed only a few were used to be MDS (Minimum Data Set). The results of data processing may indicate that MDS for the soil samples of Wonogiri there are 4, namely C-Organic amounted to 0,548 , Bulk density 0,575 , N-total of 0.335 and 0.633 for $\mathrm{K}$ is available (Table 1 ). The calculation of soil quality done by summing the scores obtained on each land use. The assessment of the soil quality can be calculated with the formula of Soil Quality Index (SQI) as follows;

$$
\mathrm{SQI}=\mathrm{SQI}=\sum_{i=1}^{n}(\text { Wi } x \text { Si })
$$

$\mathrm{SQI}=$ soil quality index (index of soil quality); $\mathrm{Wi}=$ The weight factor (Weighting Factor) in the PC; $\mathrm{Si}=$ score on each indicator of soil quality. Here are the results of calculation of soil quality in the 11 soil samples in Wonogiri regency.

Table 1. Soil Quality Value on Each Sampling Point

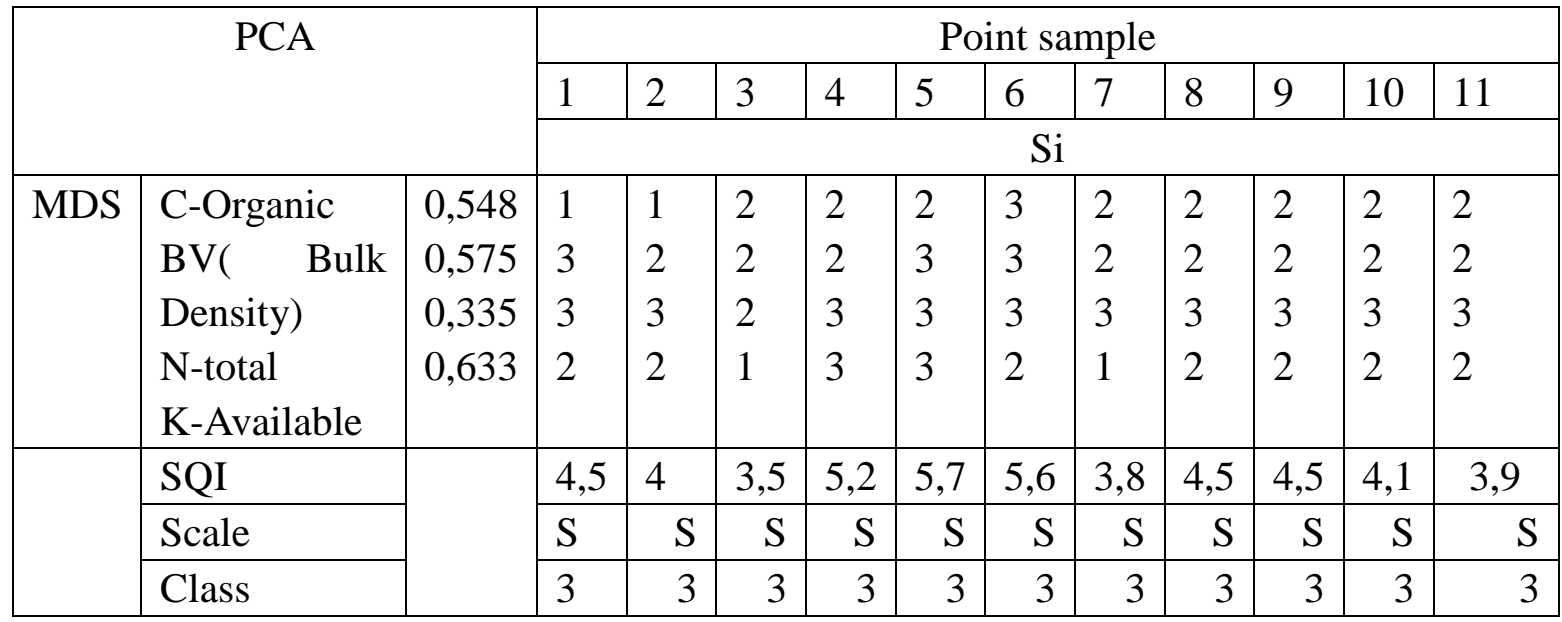




\section{Mll Macrothink}

The soil quality in each region varies depending on the characteristics and the process done to the soil, but the findings of the survey and analysis in the field showing a kind of soil class quality in Wonogiri. According to Kennedy and Pependick 1996 in Purwanto 2009, states that the quality of the soil is a mix between the nature of the chemical, biological and physical of the soil so that to make the soil can do its function effectively, these three components must be synchronized. The calculation of soil quality at Wonogiri paddy field soil samples using soil quality index calculation resulting different qualities in each sample (Table 1). Based on the table 1, that the soil quality is highest at point 5, is located in the Tambak merang village, Girimarto district with SQI value reached 5.7, while the sample points that have the lowest value of paddy soil quality index is the sample 3 located in Ngadirojo Kidul village in the Ngadirojo district with index value 3.5. The high value of the quality index of paddy field soil in the sample points 5 due to the high value of Bulk density, N-Total and K-Available in the area. While the soil sample 3 had the lowest soil quality among other soil samples due to the low value of total of $\mathrm{N}$ scoring indicators used as MDS.

This soil degradation that has occurred globally, according to Teshafunega (2014) some indicators of soil quality can be used as information to the farmers as executor of the field in addition to the government as well as related information in determining the appropriate land use policy. Weinhold (2009) states that the practice of land management will affect the function of the soil, so the soil intensification will certainly have an impact on the value of soil quality.

Paddy field soil is one of the intensively cultivated soils, in hopes that the productivity of paddy or other food crops can be increased. Irrigated paddy field soil with intensive cultivation system according Dobermann and Fairhust (2000) can result in the production of the range of 10-15 tons / ha. What is meant by cultivation on intensive irrigated paddy field is the paddy cultivation that is continuously done with the high use of inorganic fertilizers. The paddy production is influenced by internal factors and external factors, one of the internal factors is affected by the results of plants fotosintat. The results of plant fotosintat have been used mainly in the respiratory process and will be channeled into the plant either in the form of leaves, stems, and roots panicles. The amount of fotosintat used for charging the grain will determine by the level of paddy production per unit width.

Table 2. Paddy Productivity in Some District In Wonogiri Regency Year 2009-2013

\begin{tabular}{|c|c|c|c|c|c|c|c|}
\hline \multirow[t]{2}{*}{ No } & \multirow[t]{2}{*}{ District } & \multicolumn{5}{|c|}{$\begin{array}{c}\text { Lowland rice productivity in } 2009-2013 \\
\text { Tonnes / ha }\end{array}$} & \multirow[t]{2}{*}{ Average } \\
\hline & & 2009 & 2010 & 2011 & 2012 & 2013 & \\
\hline 1 & Nguntoronadi & 5,676 & 5,410 & 5,186 & 6,121 & 5,255 & 5,53 \\
\hline 2 & Eromoko & 6,395 & 5,340 & 5,025 & 5,844 & 6,271 & 5,775 \\
\hline 3 & Selogiri & 6,601 & 6,587 & 5,603 & 6,046 & 6,190 & 6,205 \\
\hline 4 & Wonogiri & 5,563 & 5,127 & 4,574 & 5,792 & 6,150 & 5,441 \\
\hline 5 & Ngadirojo & 5,198 & 5,807 & 5,670 & 5,540 & 5,650 & 5,573 \\
\hline 6 & Jatiroto & 5,622 & 5,747 & 5,614 & 5,408 & 5,811 & 5,64 \\
\hline 7 & Gririmarto & 6,302 & 6,026 & 5,362 & 5,910 & 5,939 & 5,908 \\
\hline
\end{tabular}




\section{MInstitute Macrothink $_{\text {Int }}$}

Source: Wonogiri in Figures 2010; 2011; 2013; 2014, BPS

Wonogiri is one of the paddy barns in Central Java with moderate to high level of productivity. The highest productivity of paddy lies in Selogiri district achieving total productivity of 6.205 tons / ha / year and the second highest total production is the Girimarto district with the productivity reached 5.908 tons / ha / year. While the lowest productivity lies in Wonogiri district with a value of 5.441 tons / ha / year (Table 2).

Productivity of the plants in an area can often be used as a consideration in viewing the estimate associated of degradation that is happening today. According to Costanza et al 1992 in Bastida et al 2006 means that land degradation will result in vital functions loss. To see the effect of the soil quality value on the productivity of paddy, it can be seen in the following histogram:

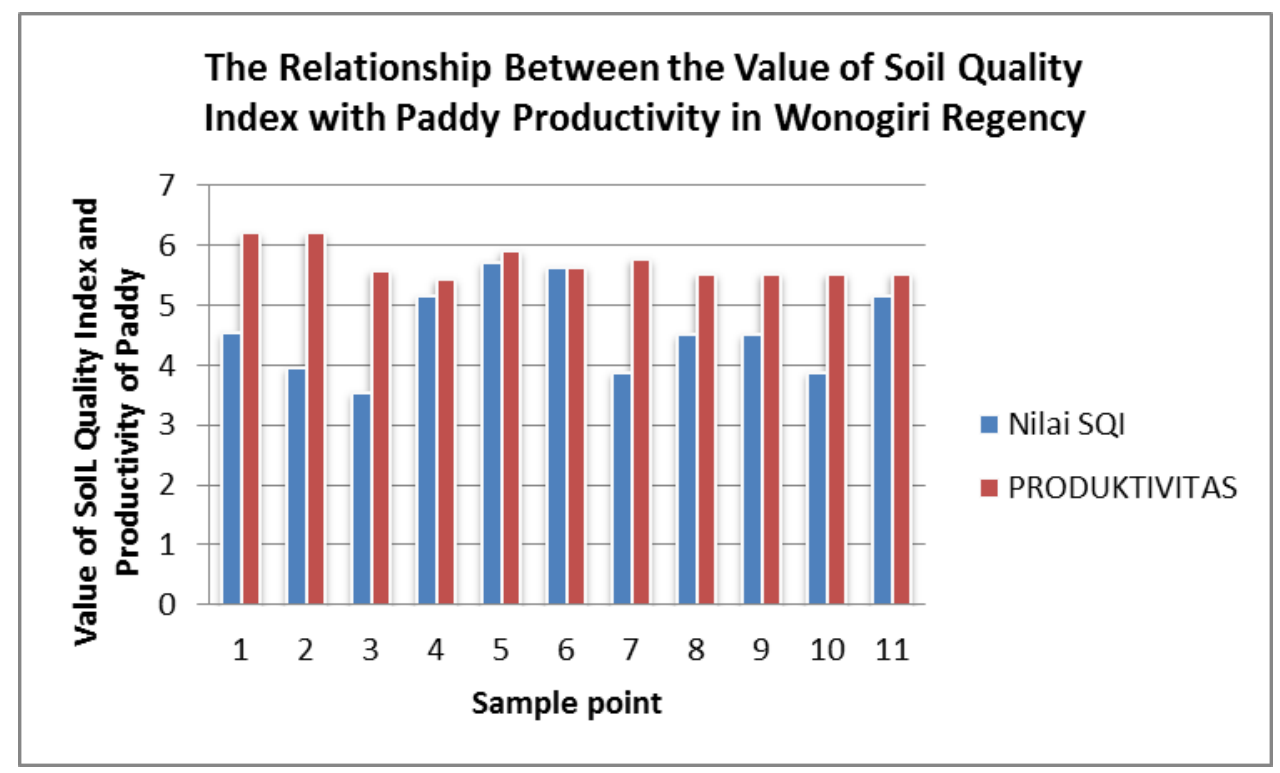

Figure 2. The Relationship between the Value of the Paddy Field Soil Quality Index with Paddy Productivity in Wonogiri Regency

According to the research by looking at the relationship between the value of the quality index of soil to the value of paddy production, it can be seen that the high productivity was offset by the high value of the soil quality, for example, it can be seen in the image in the histogram 5 in Girimarto district and Jatiroto district which have the high productivity with good soil quality too. But in the Wonogiri district and Selogiri district the high productivity values are not comparable with the low value of the soil quality. Land which has been processed continuously and intensively is resulting the decrease of soil function and crop productivity as well. According to Doran et al. (1996) maintaining the quality of the soil under intensive land use and economic development that goes fast is a major challenge to sustainable land use. 


\section{Conclusion}

Paddy field in Wonogiri has moderate soil quality index. Based on the observed sample points on each SPL, it has the sample point within a range between 3.5 in the Ngadirojo district to 5.7 located in the Girimarto district. The results obtained from the observation in the field and looking at the soil indicators, whether physical, chemical and biological indicators. From all of the indicators, the most influential is the C-Organic,Bulk Density, $\mathrm{N}$-total and K-Available in the soil. Between each of the soil indicators there are negative correlation and positive correlation. While the correlation between the quality of the soil and paddy productivity is used as an assessment of the sustainability practices of paddy cultivation land. With the result that the higher values of soil quality, the higher value of paddy productivity is, conversely the lower the quality of the soil value, the lower the value the paddy productivity. The highest productivity of paddy lies in Selogiri district achieving total productivity of 6.205 tons / ha / year and the second highest total production is in Girimarto district with productivity reached 5.908 tons / ha / year. While the lowest productivity lies in Wonogiri district with a value of 5.441 tons / ha / year.

\section{Acknowladgment}

The research was funded by the Commodity Research Universities-UNS with the title "Land Damage Index Relations with Biomass Production of Rice in Central Java" with total overall cost is Rp. 360,000,000.00. From the results of research in getting expected to be a consideration of local governments and the central government in determining policies related to land pengelolahan techniques are still protecting the environment.

\section{References}

Bastida, F., Moreno, J. L., Hernandez, T., \& Garcia, C. (2006). Microbiological degradation index of soils in a semiarid climate. Soil Biology and Biochemistry, 38, 3463-3473.

https://doi.org/10.1016/j.soilbio.2006.06.001

Bezbaruha, R., Sharma, R. C., \& Banik, P. (2011). Effect of Nutrient Management and Planting Geometry on Productivity of Hybrid Rice (Oryza sativa L.) Cultivars. American Journal of Plant Sciences, 2, 297-302. https://doi.org/10.4236/ajps.2011.23033

BPS (Badan Pusat Statistik) (2013). Jawa Tengah dalam Angka. Penertbit Badan Pusat Statistik Prov. Jawa Tengah.

Danapriatna, N., Simarmata, T, \& Nursinah, I. Z, (2012). Pemulihan Kesehatan Tanah Sawah Melalui Aplikasi Pupuk Hayati Penambat $\mathrm{N}$ dan Kompos Jerami Padi. J. Agribisnis dan Pengembangan Wilayah, 3(2), 1-8.

Dinas Pertanian Wonogiri (2012). Wonogiri Dalam Angka 2013.

http://humas.wonogirikab.go.id/.

Dobermann. A., \& Fairhust, T. (2000). Rice: Nutrient Disorders and Nutrient Management. International Rice Reasearch Institute. ISBN 981-04-2742-5.

Doran, J. W., Sarantonio, M., Leibig, M. (1996). Soil Health and Sustainbility: in : sparks. 
D.L. Advances in Agronomy. San Diego, CA, USA: Academic Press.

Eswaran, H., Almaraz, R., Breg, Reich, P. (1996). An Assessment of the Soil Resources of Africa in Relation to Productivity.

http://www.nrcs.usda.gov/wps/portal/nrcs/detail/soils/use/?cid=nrcs142p2_054023.

Franzlubbers, Alan, J., \& Haney, Richard, L. (2006). Assesing Soil Quality In Organic Agriculture. USDA Agricultural Research Service.

Gelaw, Aweke, M., Singh, B. R., Lal, R. (2015). Soil Quality Indices for Evaluating Smallholder Agricultural Land Uses in Northern Ethiopia. Journal Sustainability. 7, 2322-2337. https://doi.org/10.3390/su7032322

Kalu, S., Koirala, M., Khadka, U. R., Anup, K. C. Soil Quality Assessment for Different Land Use In the Panchase Area of Western Nepal. Journal of Enviromental Protection., 5(1), $38-43$.

Karlen, D. L., Ditzler, C. A., Andrews, S. S. (2003). Soil Quality: Why and How. J. Geoderma, 114, 145-156 (Abstr). https://doi.org/10.1016/s0016-7061(03)00039-9

Pemerintah Kabupaten. (2015). Keadaan Alam Wonogiri. http://www.wonogirikab.go.id/ . Diakses Tanggal 27 Januari 2016.

Purwanto, S. Hartati, S. Istiqomah. (2014). Pengaruh Kualitas dan Dosis Sersah Terhadap Potensi Nitrifikasi Tanah dan Hasil Jagung Manis. Sains Tanah- Jurnal Ilmu Tanah dan Agroklimatologi., 11(1),11-20. https://doi.org/10.15608/stjssa.v11i1.204

Quintero, M., \& Comerford, N. B. (2013). Effect of Conservation Tillage on Total and Aggregated Soil Organic Carbon in The Andes. J.Soil Science 3, 361-373.

https://doi.org/10.4236/ojss.2013.38042.

Supriyadi, R. Sudaryanto, Purwanto, Sri, Hartati. (2014). Kualitas Tanah: Menuju Pertanian yang Berkelanjutan. Yuma Pustaka: Surakarta.

Tesfahunegn, G. B. (2014). Soil Quality Assessment Strategies for Evaluating Soil Degradation in Northern Ethiopia. Hindawi Publishing Corporation. Applied and Environmental Soil Science. Article ID 646502.

Wienhold, B. J., \& Karlen, D. L. Andrews SS and Stott DE. Protocol For Indicator Scoring In The Soil Management Assesssment Framework (SMAF). Renewable Agriculture and Food System, 24(4), 260-266. https://doi.org/10.1155/2014/646502

\section{Copyright Disclaimer}

Copyright for this article is retained by the author(s), with first publication rights granted to the journal.

This is an open-access article distributed under the terms and conditions of the Creative Commons Attribution license (http://creativecommons.org/licenses/by/4.0/). 